\title{
Improvement in fermentation process and curd quality of yoghurt made from antimicrobial drug added milk
}

\author{
Abdul Samad Mangsi ${ }^{1}$, Muhammad Ghiasuddin Shah ${ }^{2}$, Aijaz Hussain \\ Soomro $^{3}$, Asad Ali Khaskheli ${ }^{*}$ and Arab Khan Lund ${ }^{1}$ \\ 1. Department of Dairy Technology, Shaheed Benazir Bhutto University of Veterinary \& Animal Sciences, \\ Sakrand-Pakistan \\ 2. Department of Veterinary Anatomy \& Histology, Faculty of Animal Husbandry \& Veterinary Sciences, Sindh \\ Agriculture University, Tandojam-Pakistan \\ 3. Institute of Food Sciences and Technology, Faculty of Crop Production, Sindh Agriculture University, \\ Tandojam-Pakistan \\ 4. Department of Animal Nutrition, Faculty of Animal Husbandry \& Veterinary Sciences, Sindh Agriculture \\ University, Tandojam-Pakistan \\ *Corresponding author's email: khaskhelias@gmail.com \\ Citation \\ Abdul Samad Mangsi, Muhammad Ghiasuddin Shah, Aijaz Hussain Soomro, Asad Ali Khaskheli and Arab \\ Khan Lund. Improvement in fermentation process and curd quality of yoghurt made from antimicrobial drug \\ added milk. Pure and Applied Biology. Vol. 10, Issue 3, pp738-743. \\ http://dx.doi.org/10.19045/bspab.2021.100075
}

\begin{tabular}{llll}
\hline \hline Received: 23/09/2020 & Revised: 20/11/2020 & Accepted: 25/11/2020 & Online First: 01/12/2020 \\
\hline \hline
\end{tabular}

\section{Abstract}

This study was planned to note the influence of different antimicrobial drugs (gentamicin, oxytetracycline, penicillin $\mathrm{G}$ and sulphadimidine each at level of $150 \mu \mathrm{gkg}^{-1}$ ) on the fermentation during yoghurt making, and an approach was also applied to improve the curd quality of product by addition of gelatin. Study revealed noticeable effect of residues on the fermentation of milk. The milk sample added with antimicrobial drugs reached at required level of $\mathrm{pH}$ (4.70) up to 6hrs, while with addition of gelatin to antimicrobial drug added milk the desired level of $\mathrm{pH}$ achieved at $5 \mathrm{hrs}$ against control milk which acquired to this $\mathrm{pH}$ within $3 \mathrm{hrs}$ of time. In term of syneresis, the curd quality of yoghurt was markedly $(\mathrm{P}<0.05)$ affected by residues of gentamicin, followed by penicillin $\mathrm{G}$, oxytetracycline and sulphadimidine. Significant $(\mathrm{P}<0.05)$ improvement in curd quality of yoghurt made from spiked milk was found with addition of gelatin. Concluded that the antimicrobial drugs had remarkable effect on fermentation process and curd quality of yoghurt as well but it could be improved in some extent by the addition of gelatin to residual contaminated milk.

Keywords: Antibiotic; Curd quality; Fermentation; Milk; Yoghurt

Introduction

Antimicrobial drugs not only inhibit or kill the disease organisms in man or animal but also inhibit the bacteria used to produce fermented dairy products. Therefore the residues of these agents in milk pose not only problem in consumers' health but also a threat to the quality of manufactured dairy products. Many years ago, it has been indicated that the presence of antimicrobial drug residues in milk was considered primarily a manufacturing problem related to inhibition of cheese and yoghurt starters [1]. Tamime \& Robinson [2] reported that antimicrobial residues in milk may inhibit the activity of starter cultures used to manufacture dairy products. It has been reported that the 
concentrations of penicillin G, streptopenicillin $\mathrm{G}$, and oxytetracycline given by intramuscular injection made it unsuitable for yoghurt production up to $24 \mathrm{hrs}$ but when these drugs were given by intra-mammary infusion, excreted in milk with harmful concentrations for yoghurt production up to 72, 96, and $116 \mathrm{hrs,}$ respectively [3]. Milk with different levels of antibiotic residues incubated at $44^{\circ} \mathrm{C}$ for $3.5 \mathrm{hrs}$ during yoghurt production, the coagulation time and syneresis increased but viscosity and acidity values were decreased and also lacked in the desire body and structure of yoghurt [4]. The most important jeopardy of milk to be used for yoghurt in the presence of antibiotics causes economic loss of factory due to lack of starter culture activity and fail to obtain smooth gel $[5,6]$. The presence of even small quantities of antibiotics in milk was found to create problems in dairy industry. Inadequate curdling of milk and improper ripening of cheese during their production, decreased acid and flavor production in cultured products, interference with starter culture resulting in loss of production and difficulties in validation of certain quality control tests have been reported to be commonly encountered problems [7]. Considering such adverse effects of antimicrobial drug residues, present study was carried out to observe influence of antimicrobial drug residues on fermentability trend and curd quality of yoghurt. Parallel to this, the gelatin in milk base was also added to study its influence on curd quality of yoghurt.

\section{Materials and Methods}

The antibiotic free buffalo milk (known) collected was brought to the Laboratory of Department of Animal Products Technology, Faculty of Animal Husbandry and Veterinary Sciences, Sindh Agriculture University, Tandojam. It was portioned into five equal parts and marked with A, B, C, D, E codes. All the samples were added with gentamicin, oxytetracycline, penicillin $\mathrm{G}$ and sulphadimidine each at $150 \mu \mathrm{gkg}^{-1}$ level except sample E that was kept antibiotic free (control). All the coded samples were further divided into sub-groups as $\mathrm{A}_{1}, \mathrm{~A}_{2}$; $\mathrm{B}_{1}, \mathrm{~B}_{2} ; \mathrm{C}_{1}, \mathrm{C}_{2} ; \mathrm{D}_{1}, \mathrm{D}_{2}$. Spiked samples in sub-groups coded with $\mathrm{A}_{1}, \mathrm{~B}_{1}, \mathrm{C}_{1}, \mathrm{D}_{1}$ were kept as without addition of gelatin and $\mathrm{A}_{2}$, $\mathrm{B}_{2}, \mathrm{C}_{2}$ and $\mathrm{D}_{2}$ were added with $0.2 \%$ gelatin before fermentation process. The spiked and control samples were processed for the fermentation [2]. Samples were pasteurized at $90^{\circ} \mathrm{C}$ for $10 \mathrm{~min}$ and cooled to $45^{\circ} \mathrm{C}$ in running tap water. These were then inoculated with starter culture $(3.0 \%)$ and incubated in water bath at $40^{\circ} \mathrm{C}$ till $\mathrm{pH}$ decreases in a range of 4.5 to 4.7 . The trend of decrease in $\mathrm{pH}$ was noted with interval of $1 \mathrm{hr}$ till $\mathrm{pH}$ reaches in between 4.5 to 4.7 to observe the effect of antimicrobial drug residues on the fermentability. The experiment was repeated three times to observe the statistical differences.

\section{Extent of serum separation (syneresis)}

All the control/spiked samples of milk base (with and/or without gelatin) after the fermentation were processed to observe the extent of serum separation (syneresis). The syneresis was estimated using a drainage test according to the method reported by [8]. The sample (20g) was placed on mesh $(0.4 \mathrm{~mm})$ and transferred to refrigerator for two hours at 5 to $8^{\circ} \mathrm{C}$. The drained liquid was measured.

\section{Statistical analysis}

The data so obtained was tabulated and processed through statistical procedure of analysis of variance (ANOVA) to observe the significant differences among the variables by computerized statistical package i.e. Student Edition of Statistix (SXW), Version 8.1 (Copyright 2005, Analytical Software, USA). In case of significant differences appeared among the means, the least significant difference (LSD) test at 5\% level of probability was applied [9].

\section{Results and Discussion \\ Effect of antimicrobial drugs residues on the fermentation of milk}


Results shown in (Fig. 1) indicated that the decrease in $\mathrm{pH}$ or fermentability trend during the yoghurt preparation was delayed significantly $(\mathrm{P}<0.05)$ in milk base added with antimicrobial drugs compared to control (antibiotic free). The control milk base achieved required $\mathrm{pH}$ values (4.70) within $3 \mathrm{~h}$ of time, and contrast to this, milk base spiked with antimicrobial drugs acquired the relatively similar $\mathrm{pH}$ values (4.74) up to $6 \mathrm{~h}$ of time. While, addition of gelatin to milk base reduced the fermentation period up to $5 \mathrm{~h}$. Similarly in many other studies it has been reported that the concentration of antibiotics in the milk delayed the acid production and prolonged the fermentation process/time of milk as compared to the milk free from antibiotics [4, 10, 11]. In another study increased coagulation time in the production of yoghurt which was attributed with high antibiotic residues. The delayed of coagulation time of fermentability process is due to the profound inhibitory effect of antimicrobial residues on the growth of yoghurt starter culture (Sharma, 2006). This has been confirmed in the current study, whereby findings presented in (Table 1) show that the control yoghurt acquired the desired level of $\mathrm{pH}$ in $3 \mathrm{hrs}$, while yoghurt with antibiotics like penicillin $\mathrm{G}$, gentamicin and oxytetracycline acquired the required level of $\mathrm{pH}$ within $6 / 7$ hours of incubation except yoghurt with sulphonamide, where it obtained the desired level of $\mathrm{pH}$ in $4 / 5$ hours of incubation [12]. It has been stated that the low concentrations of penicillin $G$ is bacteriostatic, while high concentration is bactericidal. With effect of penicillin $G$ some morphologic, cultural dying characteristics of bacteria may change and metabolic activity may also be halt [4]. However, [13] reported that the milk samples treated with oxytetracycline and gentamicin, and inoculated a yoghurt bacterial culture to observe their yoghurt making ability, were not fermented normally but fermentation was badly inhibited. Moreover, [12] stated that even low levels of antimicrobials in milk, increase the incubation time beyond 4 hours.

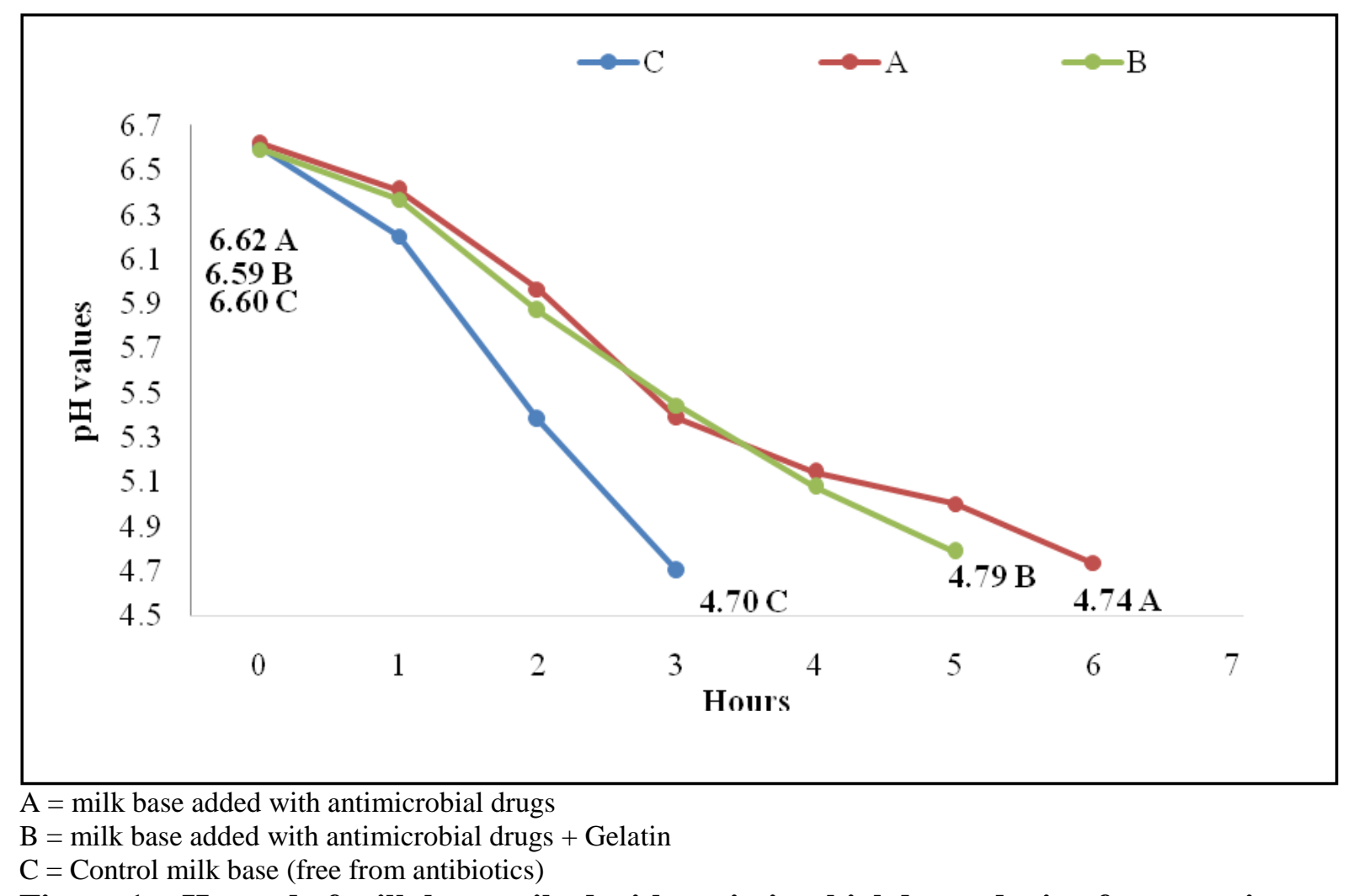

Figure 1. pH trend of milk base spiked with antimicrobial drugs during fermentation 
Table 1. Factorial analysis of variance for the mean $\mathrm{pH}$ values of milk base added with antimicrobial drugs during fermentation

\begin{tabular}{|c|c|c|c|c|c|c|c|c|c|}
\hline \multirow{2}{*}{$\begin{array}{c}\text { Antimicrobial } \\
\text { Drug } \\
\left(150 \mu \mathrm{gkg}^{-1}\right)\end{array}$} & \multirow{2}{*}{ 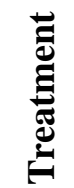 } & \multicolumn{8}{|c|}{ pH value during fermentation } \\
\hline & & $\mathbf{0 h}$ & 1h & $2 \mathrm{~h}$ & $3 \mathbf{h}$ & $4 h$ & $5 \mathbf{h}$ & $6 \mathbf{h}$ & $7 \mathrm{~h}$ \\
\hline Control & $\mathrm{A}$ & $6.60^{\mathrm{d}}$ & $6.20^{\mathrm{f}}$ & $5.38^{\mathrm{g}}$ & $4.70^{\mathrm{e}}$ & - & - & - & - \\
\hline \multirow{2}{*}{ Penicillin G } & A & $6.61^{\mathrm{c}}$ & $6.39^{\mathrm{d}}$ & $6.18^{\mathrm{b}}$ & $5.76^{\mathrm{a}}$ & $5.41^{\mathrm{a}}$ & $5.13^{\mathrm{a}}$ & $4.82^{\mathrm{a}}$ & 4.70 \\
\hline & $\mathrm{B}$ & $6.63^{\mathrm{b}}$ & $6.28^{\mathrm{e}}$ & $6.00^{\mathrm{d}}$ & $5.63^{\mathrm{b}}$ & $5.38^{\mathrm{b}}$ & $4.98^{\mathrm{b}}$ & $4.69^{\mathrm{b}}$ & - \\
\hline \multirow{2}{*}{ Oxytetracycline } & $\mathrm{A}$ & $6.62^{\mathrm{b}}$ & $6.53^{\mathrm{a}}$ & $6.25^{\mathrm{a}}$ & $5.62^{\mathrm{b}}$ & $5.21^{\mathrm{d}}$ & $4.91^{\mathrm{c}}$ & $4.70^{\mathrm{b}}$ & - \\
\hline & $\mathrm{B}$ & $6.58^{\mathrm{e}}$ & $6.46^{\mathrm{b}}$ & $6.08^{\mathrm{c}}$ & $5.62^{\mathrm{b}}$ & $5.22^{\mathrm{d}}$ & $4.70^{\mathrm{d}}$ & - & - \\
\hline \multirow{2}{*}{ Gentamicin } & $\mathrm{A}$ & $6.61^{\mathrm{c}}$ & $6.54^{\mathrm{a}}$ & $6.22^{\mathrm{a}}$ & $5.68^{b}$ & $5.26^{\mathrm{c}}$ & $4.97^{\mathrm{b}}$ & $4.69^{\mathrm{b}}$ & - \\
\hline & $\mathrm{B}$ & $6.56^{\mathrm{f}}$ & $6.44^{\mathrm{c}}$ & $5.76^{\mathrm{e}}$ & $5.39^{c}$ & $5.01^{\mathrm{e}}$ & $4.69^{\mathrm{d}}$ & - & - \\
\hline \multirow{2}{*}{ Sulphadimidine } & $\mathrm{A}$ & $6.67^{\mathrm{a}}$ & $6.39^{\mathrm{d}}$ & $5.79^{\mathrm{e}}$ & $5.18^{\mathrm{d}}$ & $4.70^{\mathrm{g}}$ & - & - & - \\
\hline & $\mathrm{B}$ & $6.61^{\mathrm{c}}$ & $6.28^{\mathrm{e}}$ & $5.64^{\mathrm{f}}$ & $5.13^{\mathrm{d}}$ & $4.70^{\mathrm{g}}$ & - & - & - \\
\hline $\operatorname{LSD}(0.05)$ & & 0.0097 & 0.0140 & 0.0459 & 0.0590 & 0.0310 & 0.0437 & 0.0479 & \multirow{2}{*}{ NS } \\
\hline $\mathrm{SE} \pm$ & & 0.0047 & 0.0068 & 0.0225 & 0.0288 & 0.0151 & 0.0214 & 0.0234 & \\
\hline
\end{tabular}

$\mathrm{A}=$ Milk without gelatin, $\mathrm{B}=$ Milk with gelatin (0.2\%), NS= Non Significant

Effect of antimicrobial drugs residues on the curd quality of yoghurt

In current study, the delay in decrease of $\mathrm{pH}$ value / fermentability trend was found less when gelatin (@0.2\%) was added to penicillin $\mathrm{G}$, oxytetracycline, gentamicin and sulphadimidine spiked milk compared to that of antimicrobial drug spiked milk without addition of gelatin (Table 2). This could suggest that incase of milk contaminated with antimicrobial drug residues the addition of gelatin during yoghurt manufacturing become effective to reduce the delay in fermentation and improve the quality of yoghurt in some extent. The curd quality of antimicrobial drug spiked yoghurt in term of syneresis was observed in current study. It was observed (Fig. 2) that in contrast to syneresis in control yoghurt $\left(1.60 \mathrm{ml} \mathrm{h}^{-2}\right)$, the syneresis appeared comparatively higher $(\mathrm{P}<0.05)$ in gentamicin spiked milk base yoghurt (3.25) followed by penicillin $G$ oxytetracycline and sulphadimidine $\left(3.08 \mathrm{ml} \mathrm{h}^{-2}, 2.83 \mathrm{ml} \mathrm{h}^{-2}\right.$ and $2.66 \mathrm{ml} \mathrm{h}^{-2}$, respectively) spiked milk base yoghurt. Further, results appeared in (Fig. 2) illustrate that the extent of serum separation in yoghurt prepared from antimicrobial drug spiked milk base with gelatin $\left(1.79 \mathrm{ml} \mathrm{h}^{-2}\right)$ was although at acceptable level, but it was still significantly $(\mathrm{P}<0.05)$ high from that of control yoghurt $\left(1.6 \mathrm{ml} \mathrm{h}^{-2}\right)$. The results of [4] are in line of present findings, they reported that the effect of antibiotic spiked milk base on syneresis varied with dose where high antibiotic concentration resulted in more syneresis volume and the least was in control yoghurt. It is probably due to the breakdown in the associative growth between $S$. thermophilus and $L b$. bulgaricus caused by antibiotic residues, resulting in slowdown in the rate of acid development and this can, in turn, lead to syneresis or wheying off [2]. Moreover, in present investigation the syneresis in yoghurt prepared from milk base spiked with antimicrobial drugs was significantly $(\mathrm{P}<0.05)$ improved with addition of gelatin. It has been observed that use of gelatin in the yoghurt as stabilizer, significantly reduced the extent of syneresis and also increase the acidity in some extent during fermentability trend, and resulted as improved quality of yoghurt [14]. This might be due to effective immobilization of the aqueous phase by the gelatin in the yoghurt network which thus significantly reduced the susceptibility to syneresis [15]. It is worth noting that large amounts of gelatin 
would induce the formation of a gel yogurt mixture [16].

network with the sodium caseinate in the

Table 2. Influence of spiked antimicrobial drugs on the curd quality of yoghurt with and without gelatin

\begin{tabular}{|c|c|c|c|c|c|}
\hline \multirow{2}{*}{$\begin{array}{c}\text { Spiked antimicrobial } \\
\text { Drug }\end{array}$} & \multirow{2}{*}{ Treatment } & \multicolumn{3}{|c|}{$*_{\text {Syneresis }}\left(\mathrm{ml} \mathrm{h}^{-2}\right)$} & \multirow{2}{*}{$\begin{array}{c}* * \text { Overall } \\
\text { Syneresis }(\mathbf{m} \\
\left.\mathbf{h}^{-2}\right)\end{array}$} \\
\hline & & Trial-1 & Trial-2 & Trial-3 & \\
\hline Control & A & $1.65^{\mathrm{i}-1}$ & $2.15^{\mathrm{gh}}$ & $1.00^{\mathrm{m}}$ & $1.60^{\mathrm{d}}$ \\
\hline \multirow{2}{*}{ Penicillin G } & A & $3.10^{\mathrm{b}-\mathrm{d}}$ & $4.05^{\mathrm{a}}$ & $2.75^{\mathrm{de}}$ & $3.30^{\mathrm{a}}$ \\
\hline & $\mathrm{B}$ & $1.80^{\mathrm{h}-\mathrm{k}}$ & $2.25^{\mathrm{fg}}$ & $1.35^{\mathrm{lm}}$ & $1.80^{\mathrm{d}}$ \\
\hline \multirow{2}{*}{ Oxytetracycline } & $\mathrm{A}$ & $2.85^{\mathrm{c}-\mathrm{e}}$ & $3.45^{\mathrm{b}}$ & $2.20^{\mathrm{gh}}$ & $2.83^{\mathrm{b}}$ \\
\hline & B & $1.65^{\mathrm{i}-1}$ & $2.10^{\mathrm{gh}}$ & $1.40^{\mathrm{k}-\mathrm{m}}$ & $1.72^{\mathrm{d}}$ \\
\hline \multirow{2}{*}{ Gentamicin } & $\mathrm{A}$ & $3.25^{\mathrm{bc}}$ & $4.10^{\mathrm{a}}$ & $3.00^{\mathrm{c}-\mathrm{e}}$ & $3.45^{\mathrm{a}}$ \\
\hline & B & $2.05^{\mathrm{g}-\mathrm{i}}$ & $2.65^{\mathrm{ef}}$ & $1.95^{\mathrm{g}-\mathrm{j}}$ & $2.22^{\mathrm{c}}$ \\
\hline \multirow{2}{*}{ Sulphadimidine } & A & $2.65^{\mathrm{ef}}$ & $3.25^{\mathrm{bc}}$ & $2.20^{\mathrm{gh}}$ & $2.70^{\mathrm{b}}$ \\
\hline & $\mathrm{B}$ & $1.55^{\mathrm{j}-1}$ & $2.00^{\mathrm{g}-\mathrm{i}}$ & $1.35^{\mathrm{Im}}$ & $1.63^{\mathrm{d}}$ \\
\hline \multicolumn{2}{|c|}{$\operatorname{LSD}(0.05)$} & \multicolumn{3}{|c|}{0.4188} & 0.2418 \\
\hline \multicolumn{2}{|l|}{$\mathrm{SE} \pm$} & \multicolumn{3}{|c|}{0.2078} & 0.1200 \\
\hline
\end{tabular}

$\mathrm{A}=$ Milk without gelatin, $\mathrm{B}=$ Milk with gelatin $(0.2 \%)$

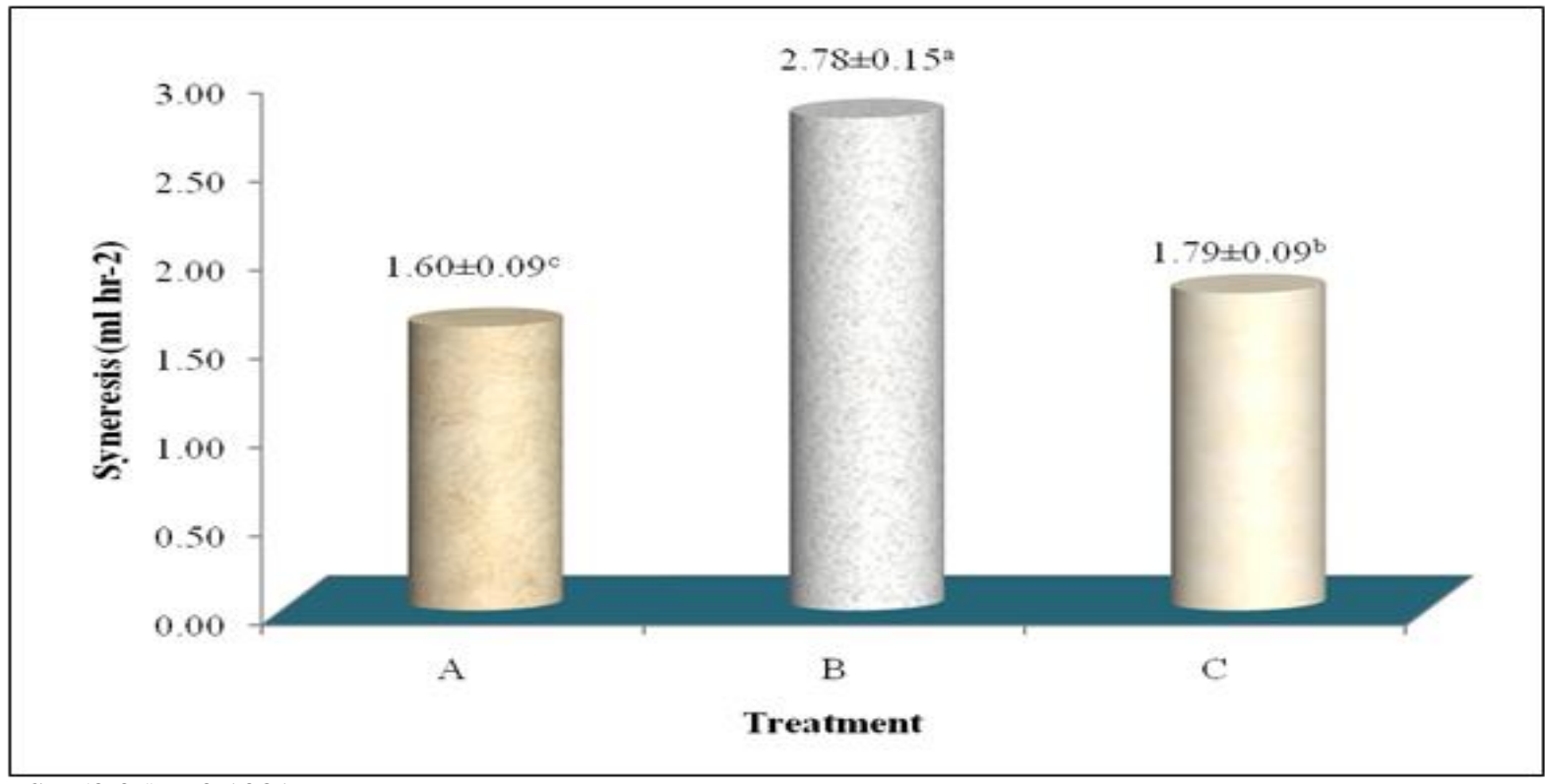

$\operatorname{LSD}(0.05)=0.1081$

$\mathrm{SE} \pm=0.0537$

Yoghurt made from buffalo milk:

$\mathrm{A}=$ Free from antimicrobial drugs (control)

$\mathrm{B}=$ Spiked with antimicrobial drugs $\left(150 \mu \mathrm{gkg}^{-1}\right)$

$\mathrm{C}=$ Spiked with antimicrobial drugs $\left(150 \mu \mathrm{gkg}^{-1}\right)+$ Gelatin $(0.2 \%)$

Figure 2. Overall effect of treatments on the syneresis (extent of serum separation) in yoghurt made from buffalo milk spiked with antimicrobial drugs

\section{Conclusion}

The spiked antimicrobial drugs delayed the fermentation process of milk base from 6 to $7 \mathrm{~h}$ in contrast to control milk base which acquired the required level of $\mathrm{pH}$
(4.7) within $3 \mathrm{~h}$ of time, while addition of gelatin to milk base reduced the fermentation period up to $5 \mathrm{~h}$. The gentamicin residues had remarkably $(\mathrm{P}<0.05)$ more influence on the curd 
quality / syneresis of yoghurt compared to that of penicillin $\mathrm{G}$, oxytetracycline and sulphadimidine residues, the syneresis in yoghurt prepared from milk base spiked with antimicrobial drugs significantly $(\mathrm{P}<0.05)$ improved with addition of gelatin.

\section{Authors' contributions}

Conceived and designed the experiments: AS Mangsi \& MG Shah, Performed the experiments: AS Mangsi, Analyzed the data: AK Lund, Contributed reagents/ materials/ analysis tools: AH Soomro, Wrote the paper: AA Khaskheli.

\section{References}

1. Cogan TM (1972). Susceptibility of cheese and yoghurt starter bacteria to antibiotics. American society for microbiology. Appl Microbiol 23: 960-965.

2. Tamime AY \& Robinson RK (2007). Methods of production and classification. Tamime and Robinson's yoghurt science and technology. Woodhead Publishing Ltd. Abington Cambridge, England 3: 8.

3. Emmanuel MA (1982). Excretion rates of antibiotics in milk of sheep and their effect on yoghurt production. J Dairy Sci 65: 426-429.

4. Erdogan A, Gurses M, Turkoglu H \& Sert S (2001). Some quality criteria of yoghurt made from milk added with antibiotic at different levels. Pak J Bio Sci 4:886-887.

5. Halkman AK (1991). In Agriculture Microbiology, Ankara University.

6. Demirci M, Yuksek AN \& Soysal MI (1992). In milk from to proceed end product Hasad Publ. Istanbul. J Dairy Sci 71: 1676-1681.

7. Mishra A, Singh SK, Sahni YP, Mandal TK, Chopra S, Gautam VN \& Qureshi SR (2011). HPLC determination of cloxacillin residue in milk and effect of pasteurization. Res J Pharm Bio Chemical Sci 2(3): 11.
8. Dannenberg F \& Kessler HG (1988). Effect of denaturation of Blactaglobulin on texture properties of set-style nonfat yoghurt-1. Syneresis. Milchwissenschaft 43: 632-635.

9. Gomez KA \& Gomez AA (1984). Statistical procedures for agricultural research. An International Rice Research Institute Book. United State of America.

10. Berruga MI, Molina MP, Noves MP, Roman B \& Molina M (2000). In vitro study about the effect of several Penicillins during the fermentation of yogurt made from ewes milk. Milchwissenschaft 62: 303-305.

11. Vintila C, Marcu A, Vinilal T, Vintila DR \& Marcu1 A (2010). Influence of antibiotics added in milk over yoghurt quality. An Sci Biotech 43: 1-3.

12. Muhammed IY, Al-Kurdi LMA, Haddadin MSY \& Robinson RK (1999). A simple test for the detection of antibiotics and other chemical residues in ex-farm milk. $J F$ Cont 10 : 35-39.

13. Yijun $\mathrm{H}$, Yewen $\mathbf{J}$ \& Songhua $\mathrm{H}$ (2007). Milk residues caused by treatment of endometritis with antibacterial drugs and effect on yoghurt production. Department of Veterinary Medicine, College of Animal Sciences, Zhejiang University, Hangzhou, Zheijiang.

14. Gupta A \& Prasad DN (2000). Use of stabilizers in cultured milk products. Ind Dairyman 52: 19-24.

15. Keogh MK \& O'Kennedy BT (1998). Rheology of stirred yogurt as affected by added milk fat, protein and hydrocolloids. J F Sci 63: 108-112.

16. Lal SND, O'Connor CJ \& Eyres L (2006). Application of emulsifiers/stabilizers in dairy products of high rheology. Ad Col and Interface Sci 123: 433-437. 